\title{
Adenosine does not bind to the growth hormone secretagogue receptor type-1a (GHS-R1a)
}

\author{
Marcos C Carreira*, Jesus P Camiña*, Esther Díaz-Rodríguez, Rodrigo Alvear-Perez , \\ Catherine Llorens-Cortes ${ }^{1}$ and Felipe F Casanueva
}

Laboratory of Molecular Endocrinology, Department of Medicine, University of Santiago de Compostela and Research Area, Complejo Hospitalario Universitario de Santiago (CHUS), PO Box 563, E-15780 Santiago de Compostela, Spain

${ }^{1}$ Institut National de la Santé et de la Recherche Médicale, Unité 691, Collège de France, 75231 Paris, France

(Requests for offprints should be addressed to F F Casanueva; Email: endocrine@usc.es)

*(M C Carreira and J P Camiña contributed equally to this work)

\begin{abstract}
Ghrelin regulates $\mathrm{GH}$ secretion and energy homeostasis through the GH secretagogue receptor type-1a (GHS-R1a). This G-protein coupled receptor shows the peculiarity to transduce information provided not just by ghrelin as well as by adenosine through a supposed binding site different from the characterized ghrelin-binding pocket. Indeed, adenosine triggers intracellular calcium rise through a distinct signaling pathway to the one described for ghrelin, although it fails to stimulate GH secretion. Despite multiple active conformations of GHS-R1a, suggested as an explanation for a ligand-dependent activation of the downstream signaling, the concept of adenosine as agonist for GHS-R1a has been re-evaluated. The results revealed that calcium rise of both ghrelin and adenosine appears to be mediated by receptors that did not show the same sensitivity to protein kinase $\mathrm{C}$ (PKC) activity in GHS-R1a-transfected HEK 293 cells (HEK-GHS-R1a cells). The binding analyses showed the
\end{abstract}

same number of adenosine-binding sites in both HEK 293 $\left(B_{\max }=2 \cdot 01 \pm 0 \cdot 15 \mathrm{fmol} / \mathrm{cell}\right)$ and HEK-GHS-R1a cells $\left(B_{\max }=1 \cdot 90 \pm 0 \cdot 11 \mathrm{fmol} / \mathrm{cell}\right)$. This binding was unaltered by different GHS-R1a antagonists. Western blot analysis showed a similar endogenous expression of endogenous adenosine receptor type- $2 \mathrm{~b}$ and -3 in both cell lines. The $K_{\mathrm{d}}$ values for adenosine were $1.78 \mu \mathrm{M}$ in HEK 293 cells and $6 \cdot 30 \mu \mathrm{M}$ in HEK-GHS-R1a cells, pointing to a modification of agonist affinity induced by overexpression of the GHSR1a. Additionally, adenosine failed to induce the GHS-R1a endocytosis, although it attenuates the ghrelin-induced GHS$\mathrm{R} 1 \mathrm{a}$ endocytosis. In conclusion, adenosine is not an agonist of the GHS-R $1 \mathrm{a}$ and its action is mediated by the endogenous adenosine receptor type- $2 \mathrm{~b}$ and -3 , which is able to partially use the intracellular signaling machinery of HEK-GHS-R1a cells.

Journal of Endocrinology (2006) 191, 147-157

\section{Introduction}

The ghrelin system is implicated in a variety of physiological events including growth hormone $(\mathrm{GH})$ release, energy homeostasis, reproduction, sleep regulation, cardiovascular actions, corticotrope secretion, stimulation of lactotrope, and influence on gastroenteropancreatic functions (Korbonits et al. 2004, van der Lely et al. 2004). The ghrelin action on growth and energy homeostasis is mediated by the growth hormone secretagogue receptor type-1a (GHS-R1a), a G-protein coupled receptor, also called the ghrelin receptor (Shuto et al. 2002, Lall et al. 2004, Sun et al. 2004, Wettschureck et al. 2005). This receptor transduces information provided by ghrelin and by the group of synthetic growth hormone secretagogues (GHSs) not related structurally to the ghrelin. This property is explained by the existence of a common binding domain demonstrated by molecular modeling and site-directed mutagenesis studies developed with GHS peptide and non-peptide agonists (Feighner et al. 1998). This binding site might determine that a conserved structure of the agonists recognizes a complementary conserved-binding pocket, which directs the variable part of the ligand and interacts with specific agonistassociated regions determining an overlapping in the agonistbinding site (Bondensgard et al. 2004). In addition, GHS-R1a appears to have other alternative ligands. This was revealed by studies carried out with adenosine (Smith et al. 2000, Tullin et al. 2000) and also with cortistatin (Deghenghi et al. 2001). Indeed, administration of adenosine to cells not expressing the GHS$\mathrm{R} 1 \mathrm{a}$ is devoid of action but when it is administered to cells expressing this receptor, adenosine triggers intracellular calcium rise, although it fails to stimulate growth hormone secretion (Tullin et al. 2000). Concerning intracellular calcium mobilization, a signaling pathway was proposed involving adenylate cyclase (AC)/protein kinase $\mathrm{A}$ (PKA)/ $\mathrm{IP}_{3}$-receptors, different from those activated by ghrelin (Carreira et al. 2004). Based on such results, it appeared that the GHS-R1a was able to activate 
different intracellular second messenger systems that appear to regulate separate agonist-dependent mechanisms for desensitization and internalization of this receptor. However, the fact that adenosine did not show cross-competition with ghrelin in binding to GHS-R1a (Camina et al. 2004, Carreira et al. 2004), a property described for cortistatin (Deghenghi et al. 2001), remained as discordant data, considering that it is a requisite to define alternative ligands for a specific receptor. It is important to note that the concept of adenosine as an agonist of GHS-R1a emerged from functional studies developed on cells overexpressing GHS-R1a. To date, there is growing evidence that high receptor expression levels, which are sometimes obtained in some cellular models, lead to unexpected interactions with other receptors that change the receptor properties and, inevitably, their functions. For this reason, we formulated the alternative hypothesis that adenosine does not bind to the GHS$\mathrm{R} 1 \mathrm{a}$ and that previous results could be fully explained by a crosstalk between two completely separated receptorial systems, the adenosine and the ghrelin systems. This is an important point taking into account, that the GHS-R1a appears to play a significant physiological role in the regulation of growth hormone secretion and, in particular, in the regulation of food intake and obesity. This converts GHS-R1a into a therapeutic target for the rational design of novel receptor ligands involved, in particular, in the regulation of the energy homeostasis. In this work, the binding characteristic and intracellular signaling activation of adenosine in cells expressing, or not, high numbers of ghrelin receptors have been addressed to assess the interplay between adenosine and ghrelin.

\section{Materials and Methods}

\section{Materials}

Human ghrelin was provided by Global Peptide (Fort Collins, CO, USA). Adenosine, D-Lys ${ }^{3}-$ GHRP-6 and [D-Arg ${ }^{1}$,DPhe ${ }^{5}, \mathrm{D}-\operatorname{Trp}^{7,9}, \mathrm{D}-\mathrm{Leu}{ }^{11}$ ]-substance $\mathrm{P}$, phorbol 12-myristate 13-acetate (PMA), and cycloheximide were obtained from Sigma. ${ }^{125} \mathrm{I}$-ghrelin, ${ }^{3} \mathrm{H}$-adenosine, and the ECL detection kit was from Amersham Pharmacia Biotech. Polyalylamine hydrochloride was provided by Sigma. Glass slides were provided by Nalge Nunc (Nalge Europe Ltd, Hereford, UK). Fura-2 pentaacetoxymethylester (fura-2/AM) was obtained from Molecular Probes (Eugene, OR, USA). Anti-adenosine A3-R (H-80) rabbit polyclonal and anti-adenosine A2b-R (R-20) goat polyclonal antibodies were obtained from Santa Cruz Biotechnology (Santa Cruz, CA, USA). Ghrelin analog BIM-28163 was a generous gift from Dr Michael Culler (IPSEN, Milford, MA, USA).

\section{HEK 293 cell line cultures}

The HEK 293 cell line that stably expresses the human ghrelin receptor 1a (HEK-GHS-R1a) was a generous gift from Dr Roy Smith. The HEK-GHS-R1a cell line was cultured in $100 \mathrm{~mm}$ dishes in high-glucose Dulbecco's modified Eagle's medium (DMEM) plus 10\% (v/v) fetal calf serum, glutamine, and penicillin-streptomycin solution plus $500 \mu \mathrm{g} / \mathrm{ml}$ geneticin G-418 to $70-80 \%$ confluence for 3 days (Camina et al. 2004). The non-transfected HEK 293 cells were seeded in $100 \mathrm{~mm}$ dishes and cultured to $80 \%$ confluence for 3 days in DMEM supplemented with 10\% $(\mathrm{v} / \mathrm{v})$ fetal calf serum. Media were supplemented with penicillin $\mathrm{G}(100 \mathrm{U} / \mathrm{ml})$ and streptomycin sulfate $(100 \mu \mathrm{g} /$ $\mathrm{ml})$. Cells were grown under a humidified atmosphere of $95 \%$ air, $5 \% \mathrm{CO}_{2}$ at $37^{\circ} \mathrm{C}$.

\section{CHO cell line cultures}

The plasmid construction of the C-terminal tagging GHSR1a with enhanced green fluorescent protein (EGFP), the transfection characteristics on $\mathrm{CHO}-\mathrm{K} 1$ cells and selection of clones expressing the GHS-R1a-EGFP have been described previously (Camina et al. 2004). The CHO-K1 cell line that stably expresses the GHS-R1a-EGFP (CHO-GHS-R1a) was cultured in $100 \mathrm{~mm}$ dishes in Ham's F12 medium supplemented with $7 \cdot 5 \%(\mathrm{v} / \mathrm{v})$ fetal calf serum, $1 \mathrm{mM}$ glutamine, $100 \mathrm{U} / \mathrm{ml}$ penicillin, and $100 \mu \mathrm{g} / \mathrm{ml}$ streptomycin. Cells were grown under a humidified atmosphere of $95 \%$ air and $5 \%$ $\mathrm{CO}_{2}$ at $37^{\circ} \mathrm{C}$.

\section{Calcium measurements}

Intracellular calcium measurements were performed in cell suspensions using the fluorescent calcium probe fura-2 as described previously (Camina et al. 2004).

\section{Whole cell-binding assay}

Confluent monolayer cells (70-80\%) were resuspended in binding buffer (containing, DMEM $(\mathrm{pH} 7 \cdot 4)$ plus $1 \%(\mathrm{w} / \mathrm{v})$ BSA), centrifuged at $500 \mathrm{~g}$ for $5 \mathrm{~min}$ at room temperature, washed twice and resuspended in proportion $1 \times 100 \mathrm{~mm}$ plate $/ 1.5 \mathrm{ml}$ (500 000 cells/aliquot) in binding buffer supplemented with the radioligand $\left({ }^{3} \mathrm{H}\right.$-adenosine, $2 \mu \mathrm{Ci} / \mathrm{ml}$; $\left[{ }^{125} \mathrm{I}\right]$-ghrelin, 100000 c.p.m./aliquot) in the absence or presence of unlabeled competitor (adenosine, $1 \mu \mathrm{M}$; ghrelin, $1 \mu \mathrm{M})$ for $2 \mathrm{~h}$ at $4{ }^{\circ} \mathrm{C}$. After incubation, media were removed and the pellet was washed twice with binding buffer at $4{ }^{\circ} \mathrm{C}$. Cell surface radioligand was determined by incubating the cells in $0.5 \mathrm{ml}$ ice-cold acid buffer (containing $0.5 \mathrm{M} \mathrm{NaCl}$; $0 \cdot 2 \mathrm{M}$ acetic acid, $\mathrm{pH} 2 \cdot 0$ ) for $10 \mathrm{~min}$ at $4{ }^{\circ} \mathrm{C}$. Finally, the cells were centrifuged and the supernatants were counted in a $\beta$ or a $\gamma$ counter. For $\beta$ counter, supernatants were mixed with scintillation liquid.

\section{Saturation analyses}

Confluent monolayer cells (about 70-80\%) were resuspended in binding buffer, centrifuged at $500 \mathrm{~g}$ for $3 \mathrm{~min}$ at room temperature, washed twice and then resuspended 
$\left(5 \times 10^{5}\right.$ cells/aliquot) in binding buffer supplemented with increasing concentrations of $\left[{ }^{3} \mathrm{H}\right]$-adenosine (from 1 to $10 \mu \mathrm{M})$ in the absence or presence of unlabeled competitor (100 times $\left[{ }^{3} \mathrm{H}\right]$-adenosine concentration used in each point) for $2 \mathrm{~h}$ at $4^{\circ} \mathrm{C}$. The media containing labeled adenosine was removed and the cells were washed twice with ice-cold binding buffer and the cell-surface bound adenosine was measured after treatment with acid buffer in a $\beta$ counter. Non-linear curve-fitting procedures (GraphPad Prism, version 4.0, GraphPad Software, Inc, San Diego, CA, USA) were used to estimate the concentration of adenosine-binding sites $\left(B_{\max }\right)$ and to calculate the $K_{\mathrm{d}}$.

Non-specific binding, determined as radioactivity bound to cells in the presence of unlabeled competitor, represented about $5 \cdot 6 \pm 1 \cdot 6$ and $6 \cdot 5 \pm 0 \cdot 3 \%$ for adenosine in HEK 293 and in HEK-GHS-R1a respectively.

\section{Internalization assay and confocal microscopy}

Trypsinized GHS-R1a-EGFP cells were diluted to obtain $10^{5}$ cells $/ \mathrm{ml}$ in Ham's F12 medium, seeded $(200 \mu \mathrm{l} /$ well $)$ on polyallylamine hydrochloride-coated (Sigma; $0.1 \mathrm{mg} / \mathrm{ml}$ for $30 \mathrm{~min}$ ) 16-well glass (Lab-Tek Chamber Slides, Nalge Nunc), and cultured overnight in a humidified atmosphere of $95 \%$ air, $5 \% \mathrm{CO}_{2}$ at $37^{\circ} \mathrm{C}$. In all experiments, $90 \mathrm{~min}$ before the beginning of the experiment, the medium was supplemented with cycloheximide (Sigma) to obtain a final concentration of $90 \mu \mathrm{M}$ in order to prevent de novo protein synthesis. Cells were pre-incubated for $30 \mathrm{~min}$ at $4{ }^{\circ} \mathrm{C}$ in ice-cold Earle's buffer (containing $25 \mathrm{mM}$ HEPES; $140 \mathrm{mM}$ $\mathrm{NaCl} ; 5 \mathrm{mM} \mathrm{KCl} ; 1.8 \mathrm{mM} \mathrm{CaCl}_{2} ; 3.6 \mathrm{mM} \mathrm{MgCl}_{2}, \mathrm{pH} 7 \cdot 4$; complemented with $0 \cdot 2 \%(\mathrm{w} / \mathrm{v}) \mathrm{BSA} ; 0 \cdot 01 \%(\mathrm{w} / \mathrm{v})$ glucose; $0.09 \mathrm{mM}$ cycloheximide; $0.8 \mathrm{mM}$ phenanthroline) in the presence or absence of different stimuli. Internalization was promoted by placing the cells at $37^{\circ} \mathrm{C}$ for 20 or $60 \mathrm{~min}$. Thereafter, the cells were rinsed three times with ice-cold Earle's buffer and subsequently fixed for $10 \mathrm{~min}$ with $4 \%$ paraformaldehyde dissolved in PBS. The cells were rinsed again in cold Earle's buffer, mounted using Vectashield (Vector Laboratories; Compiègne, France) and coverslipped for confocal microscopic examination. The cells were examined with a Leica TCS SP 2 (Leica Microsystems, Heidelberg, Germany) confocal laser scanning microscope mounted on a Leica DM IRBE inverted microscope equipped with an argon/krypton laser. EGFP fluorescence was detected with $100 \%$ excitation at $488 \mathrm{~nm}$, using an RSP 500 (dichroic) mirror and the spectrophotometer set to acquire emission between 530 and $560 \mathrm{~nm}$. Optical sections $(1024 \times 1024)$ of individual cells were taken at the equatorial level (level of the nucleus), using a $63 \times 1.32$ NA oil-immersion objective.

\section{Western blot analysis}

The cells were incubated for $10 \mathrm{~min}$ with the lysis buffer (containing $150 \mathrm{mM} \mathrm{NaCl}, 1 \mathrm{mM}$ EDTA, $50 \mathrm{mM}$
Tris-HCl, $\mathrm{pH} \quad 7 \cdot 4 ; \quad 1 \% \quad(\mathrm{v} / \mathrm{v}) \quad \mathrm{NP}-40, \quad 0 \cdot 25 \% \quad(\mathrm{v} / \mathrm{v})$ $\mathrm{Na}$-deoxycholate, $1 \mathrm{mM}$ supplemented with phenylmethylsulphonyl fluoride, $0.15 \mathrm{mM}$ aprotinin, $2.16 \mathrm{mM}$ leupeptin, $1.6 \mathrm{mM}$ pepstatin, $1 \mathrm{mM} \mathrm{Na} \mathrm{VO}_{4}, 1 \mathrm{mM} \mathrm{NaF}$ ) at $4{ }^{\circ} \mathrm{C}$. The solubilized cell lysates were pre-cleared by centrifuging at $14000 \mathrm{~g}$ for $10 \mathrm{~min}$. The protein concentration was evaluated by the Bradford method. The same amount $(30 \mu \mathrm{g})$ of protein of each sample was separated on $10 \%$ SDS-polyacrylamide gels, transferred to nitrocellulose membranes and probed with goat polyclonal antibodies directed against the adenosine receptor type-2b (A2b-R) and rabbit polyclonal antibodies directed against adenosine receptor type-3 (A3-R). The primary antibodies were detected with corresponding peroxidase-conjugated $\operatorname{IgG}$ antibody. The ECL substrate was used to reveal bands, according to the manufacturer's instructions.

\section{siRNA and cell transfection}

Adenosine A2b-R and A3-R siRNAs were purchased from Santa Cruz Biotechnology. Three different strands for each siRNA were used in order to target different parts of the same mRNA to improve the knockdown efficiency. The siRNA sequences targeting adenosine receptors, as the manufacturer indicated, were the following. For A3-R: 5'-GCAUCACAAUCCACUUCUA- $3^{\prime}, 5^{\prime}$-CAUGCCAACUCCAUGAUGA- $3^{\prime}$, and 5'-CUAGUUGACUUACUGACAA- $3^{\prime}$. For A2b-R: 5'-CACCAACAACUGCACAGAA- $3^{\prime}, 5^{\prime}$ CUACCACGUAUCUAGCUAA- $3^{\prime}$, and $5^{\prime}$-CAGCUUGAAUGGAUUCUAA- $3^{\prime}$. A non-silencing RNA duplex was used as a control (Santa Cruz Biotechnology). 40-50\% confluent cells in $100 \mathrm{~mm}$ plates, seeded $24 \mathrm{~h}$ before transfection, were transfected with siRNA using siRNA tranfection reagent (Santa Cruz Biotechnology) according to the manufacturer's modified instructions. In brief, $106.9 \mu \mathrm{l}$ transfection reagent were added to $792 \mu \mathrm{l}$ serum-free medium, while RNA mixtures containing $0.72 \mathrm{nmol}$ siRNA and $792 \mu \mathrm{l}$ serum-free medium were prepared. After $5 \mathrm{~min}$ at room temperature, both solutions were combined and allowed to stand for $20 \mathrm{~min}$ at room temperature. The transfection mixture was added to cells containing $5 \mathrm{ml}$ fresh serum-free medium. After the cells were incubated for $7 \mathrm{~h}$ at $37^{\circ} \mathrm{C}$, the medium was replaced with normal medium (serum containing). All assays were performed $48 \mathrm{~h}$ after siRNA transfection. A2b-R and A3-R expressions were determined by radioligand binding assays with $\left[{ }^{3} \mathrm{H}\right]$-adenosine, as described above.

\section{Data analysis}

The results were expressed as the mean \pm s.E.M. Differences between means were evaluated by one-way ANOVA $(\star P<0 \cdot 05)$. 


\section{Results}

Desensitization of the ghrelin and adenosine responses by protein kinase $C$

To evaluate if adenosine is a true ligand of the GHS-R1a, we monitored the intracellular calcium rise upon receptor activation. Neither ghrelin (100 nM) nor adenosine $(100 \mu \mathrm{M})$ had a significant effect on intracellular calcium mobilization on untransfected HEK 293 cells (Fig. 1A and B), which were fully responsive to lysophosphatidic acid $(1 \mu \mathrm{g} / \mathrm{ml})$ used as an internal control of cell viability. In contrast, the addition of adenosine $(100 \mu \mathrm{M})$ to HEK 293 cells that stably express the GHS-R1a (HEK-GHS-R1a cells), induced a biphasic increase of $\left[\mathrm{Ca}^{2+}\right]_{i}$ with no detectable lag period (Fig. 1D), and ghrelin (100 nM) activated a more powerful response showing similar dynamics (Fig. 1C). The ghrelin-induced $\mathrm{Ca}^{2+}$ mobilization is activated by phosphatidylinositol-specific phospholipase C, an enzyme that hydrolyzes phosphatidylinositol 4,5-biphosphate generating inositol 1,4,5-triphosphate and diacylglycerol. The formed diacylglycerol triggers the activation of PKC which, in turn, closes PKC-regulated receptors, such as L- $\alpha$-lysophosphatidic acid receptor(s), with no effect on the GHS-R1a (Camina et al. 2004). In fact, the activation of PKC activity by means of the phorbol ester PMA $(1 \mu \mathrm{M}$, $5 \mathrm{~min})$ did not alter the ghrelin-induced $\mathrm{Ca}^{2+}$ transient (Fig. 1E). However, the accurate administration of PMA $(1 \mu \mathrm{M}, 5 \mathrm{~min})$ caused a significant blockade of the adenosine-induced $\mathrm{Ca}^{2+}$ transient (Fig. 1F). These results were surprising since it was previously assumed that adenosine action is mediated through the GHS-R1a, then PKC activation should not modify the adenosine-induced calcium signal. In addition, PMA-activated PKC $(1 \mu \mathrm{M}$, $5 \mathrm{~min}$ ) caused a non-significant reduction in $\left[{ }^{3} \mathrm{H}\right]$-adenosine binding to the HEK-GHS-R1a cells (data not shown).

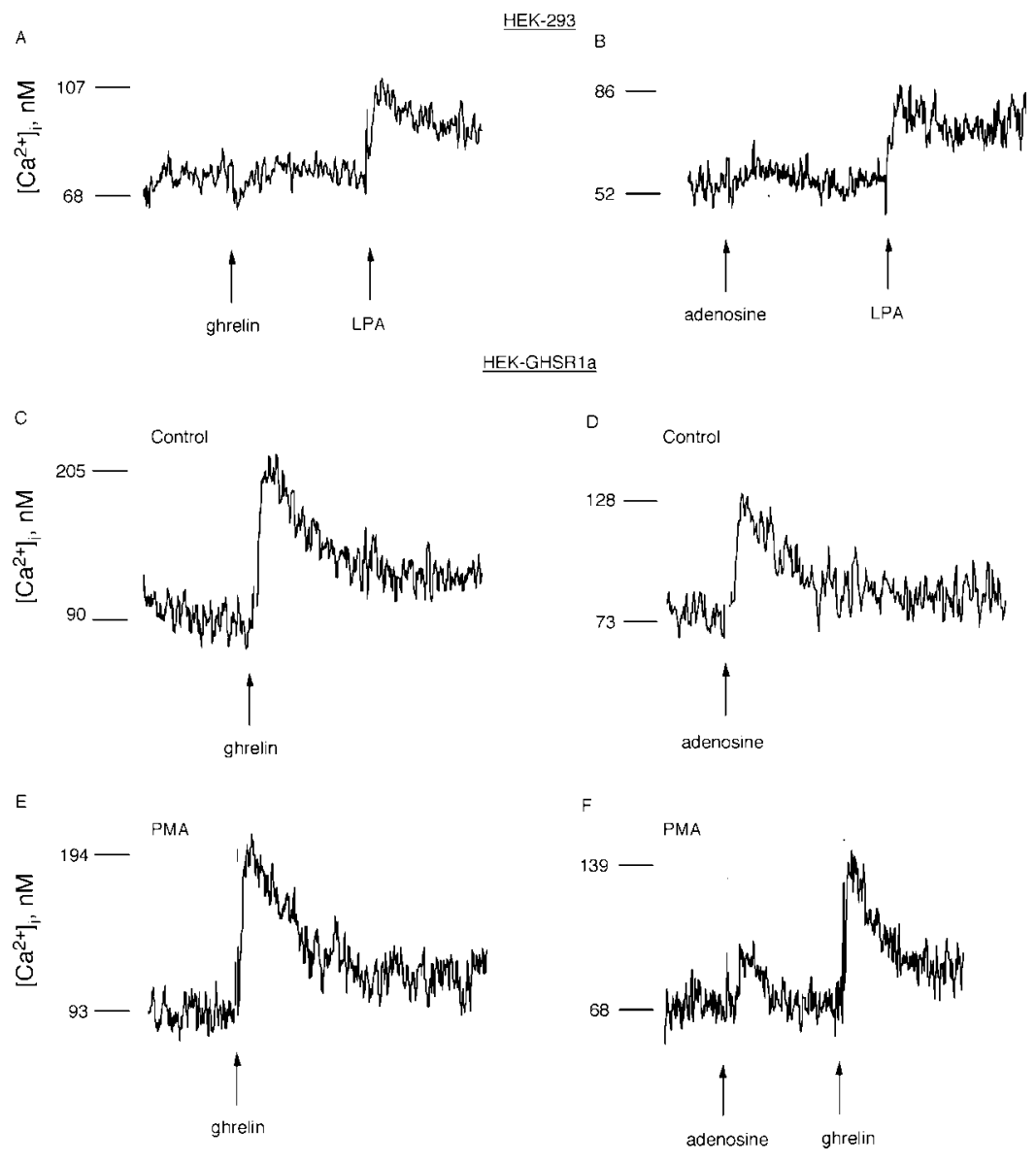

Figure 1 Effects of (A) ghrelin $(100 \mathrm{nM})$ and $(B)$ adenosine $(100 \mu \mathrm{M})$ on intracellular calcium mobilization in untransfected HEK-293 cells. Effects of (C) ghrelin (100 nM) and $(D)$ adenosine $(100 \mu \mathrm{M})$ on intracellular calcium mobilization in HEK-293 cells overexpressing the GHS-R1a. Pre-incubation in the presence of PMA (1 $\mu \mathrm{M}, 5 \mathrm{~min})$ inhibited adenosine-calcium signal $(F)$ with no effect on ghrelin calcium transient $(E, F)$. Results correspond to a representative experiment repeated six times with comparable results. 
To gain further insight into the mechanism of action of adenosine, the role of PKC in the cross-talk between the adenosine and the ghrelin signaling pathways was assessed. As Fig. 2A shows, repeated administration of a saturating dose

$$
\text { A }
$$

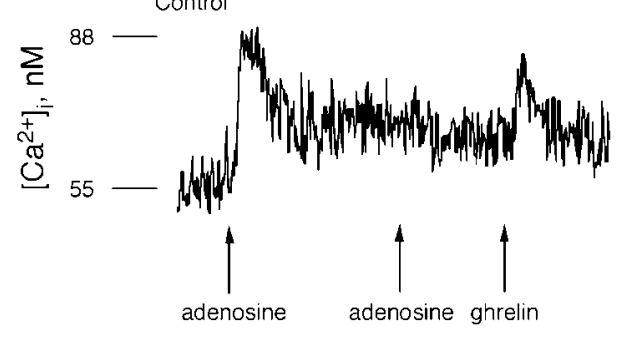

B
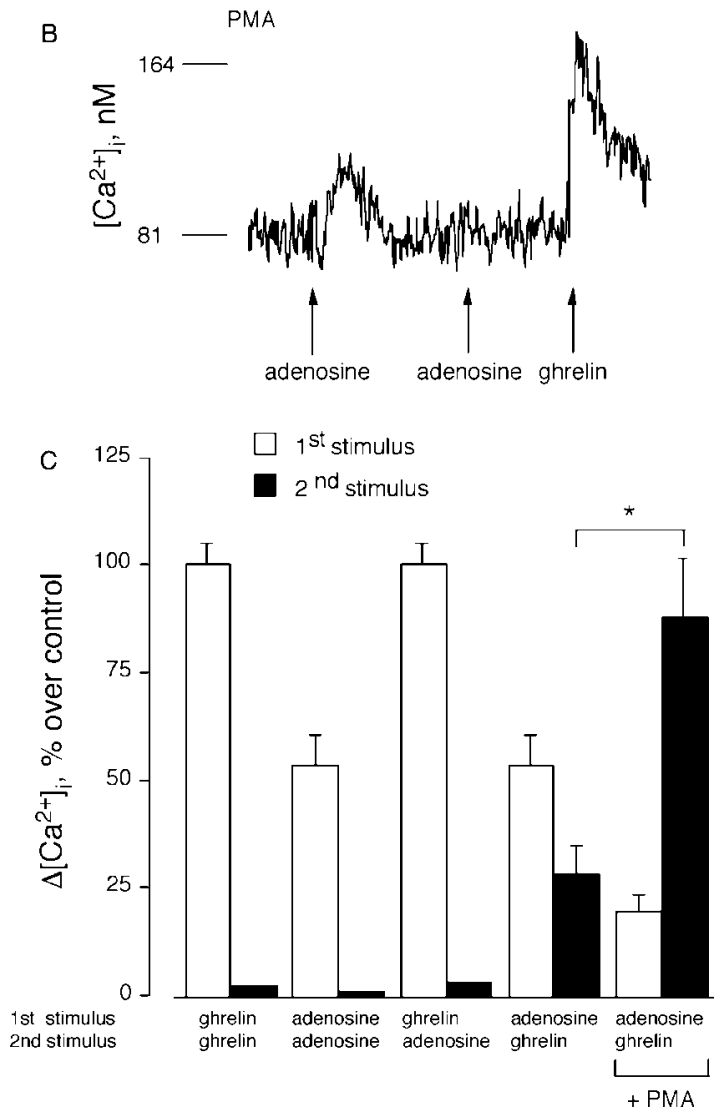

Figure 2 (A) The repeated administration of adenosine $(100 \mu \mathrm{M}$, two times) caused homologous desensitization and heterologous desensitization of ghrelin-induced calcium mobilization. (B) However, activation of protein kinase $C$ (PKC) by treatment with PMA $(1 \mu \mathrm{M})$ inhibited the adenosine-induced homologous desensitization which allows recovery of the ghrelin calcium response. (C) Bar graph shows the ghrelin-induced homologous and heterologous desensitization to adenosine, the adenosine-induced homologous desensitization, the partial reduction of the ghrelin calcium response and the effect of PKC activation on the adenosineinduced cross-desensitization on the ghrelin calcium signal $(100 \mathrm{nM} ; * P<0 \cdot 05)$. Results (mean \pm S.E.M. of three independent quadruplicate experiments) are expressed as the percentage of maximum $\mathrm{Ca}^{2+}$ response.
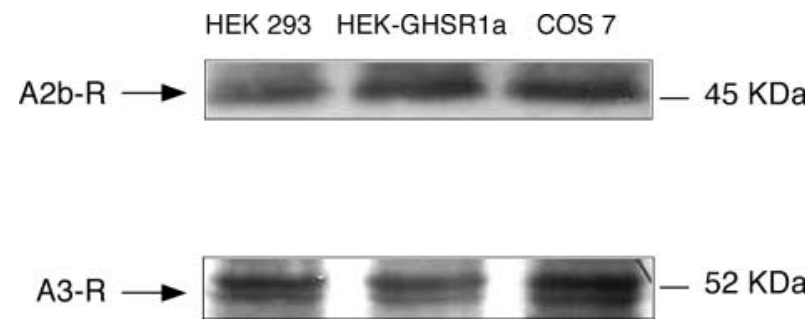

Figure 3 Western blot analysis of A2b-R and A3-R in HEK 293 and HEK-GHS-R1a cells. The apparent molecular weight was $45 \mathrm{kDa}$ for A2b-R and $52 \mathrm{kDa}$ for A3-R. COS 7 cell line was taken as positive control.
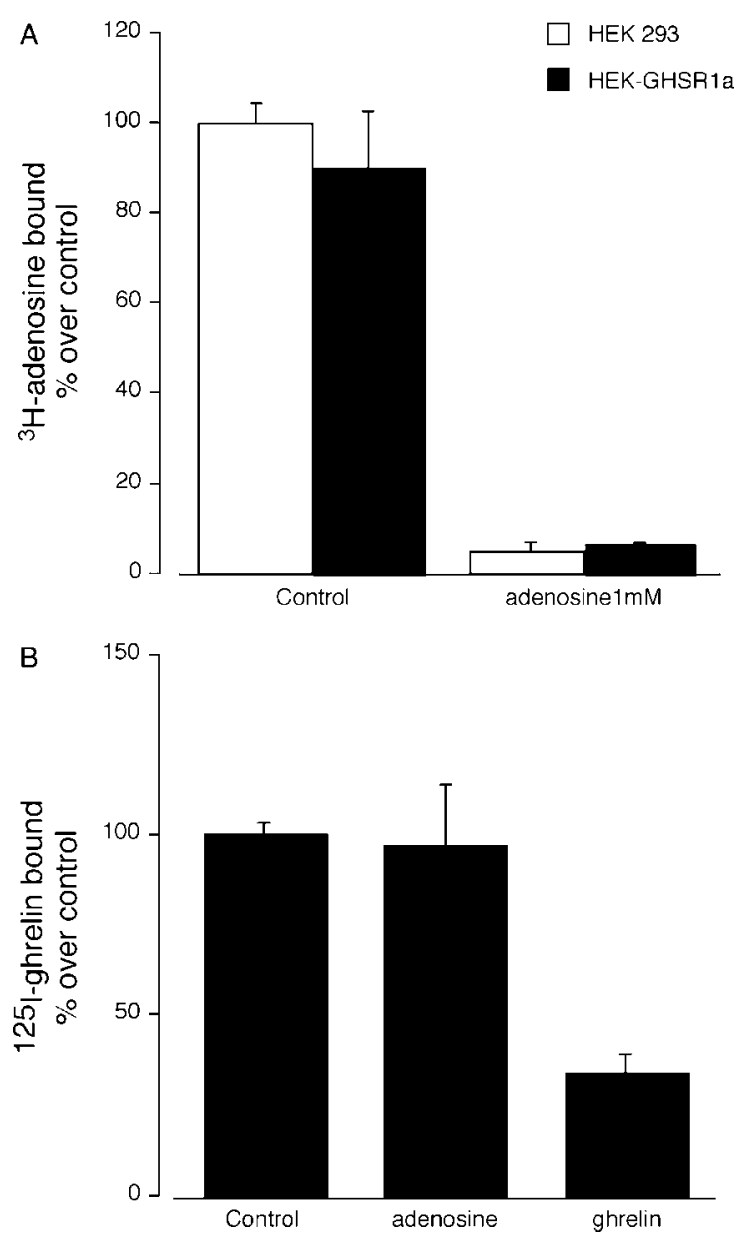

Figure 4 Competition analysis of $\left[{ }^{3} \mathrm{H}\right]$-adenosine and $\left[{ }^{125} \mathrm{I}\right]$-ghrelin in HEK 293 and HEK-GHS-R1a cells. Binding was measured at the cell surface as described in Materials and Methods in HEK 293 (open bars) and HEK-GHS-R1a (solid bars) cells. The ordinate represents binding as a percentage of control (specific binding in the absence of unlabeled competitor). (A) The amount of cell-surface bound $\left[{ }^{3} \mathrm{H}\right]$-adenosine was similar in both cellular systems. This binding was shown to be specific as bound radioligand was completely displaced by unlabeled adenosine (1 mM). (B) Binding of $\left[{ }^{125} \mathrm{I}\right]$-ghrelin was not affected by unlabeled adenosine $(1 \mathrm{mM})$ while unlabeled ghrelin $(1 \mu \mathrm{M})$ showed a complete displacement of surface bound $\left[{ }^{125} \mathrm{I}\right]$-ghrelin. Data (mean \pm s.E.M.) are from three independent triplicate experiments. 
of adenosine $(100 \mu \mathrm{M})$ induced a homologous desensitization of its transmembrane signaling system and, in addition, reduced $48 \%$ the ghrelin-induced calcium response $(P<$ $0 \cdot 05 ; n=12$; Fig. 2C). However, when PKC was preactivated by means of PMA $(1 \mu \mathrm{M}, 5 \mathrm{~min})$, adenosine was unable to cross-desensitize the ghrelin receptor (Fig. $2 \mathrm{~B}$ and C). This supports the hypothesis that adenosine-induced calcium response is mediated by a receptor with different properties from the GHS-R1a.

\section{Endogenous adenosine receptors}

Suspecting that HEK 293 cells may be endowed with adenosine receptors which become activated after transfection of the GHS-R1a, the presence of adenosine receptors on HEK cells were evaluated. As Fig. 3 shows, adenosine receptor type-2b (A2b-R) was detected in both HEK 293 and HEK-GHS-R1a whole cell lysates by western blot analysis. Furthermore, a lower expression of adenosine receptor type-3 (A3-R) was also detected (Fig. 3). Despite the fact that several studies had previously suggested the existence of endogenous A2b-R on HEK-293 cells (Cooper et al. 1997, Gao et al. 1999, Linden et al. 1999), the density of this receptor appeared to be too low to contribute to calcium activity of adenosine in these cells. To our knowledge, there is no data about the expression of A3-R on HEK-293 cells. The COS 7 cell line was taken as a positive control for these assays (Peters et al. 1998). No negative control is presented basically due to the wide distribution of both receptors (Feoktistov \& Biaggioni 1997, Ralevic \& Burnstock 1998).

\section{Radioligand binding studies}

The above functional data suggest that the adenosineactivated signaling pathway was not mediated by GHS-R1a. Binding experiments with the radioligand $\left[{ }^{3} \mathrm{H}\right]$-adenosine showed that the specific cell-surface bound $\left[{ }^{3} \mathrm{H}\right]$-adenosine was comparable in HEK 293 and HEK-GHS-R1a cells (Fig. 4A). Competitive binding assays showed that adenosine did not displace bound $\left[{ }^{125} \mathrm{I}\right]$-ghrelin in HEK-GHS-R 1a cells
A

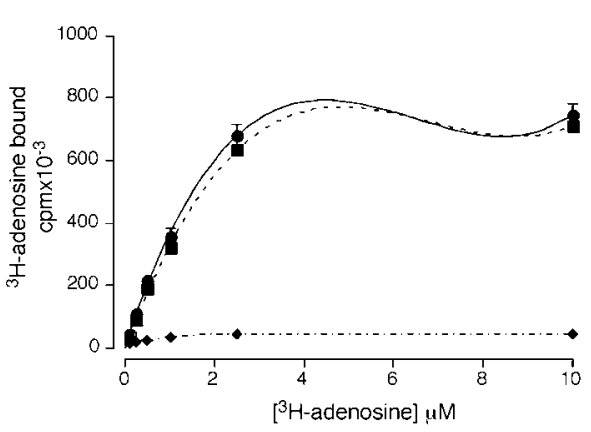

C

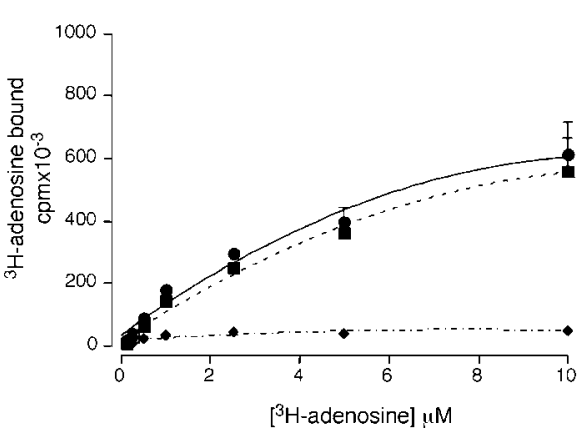

B

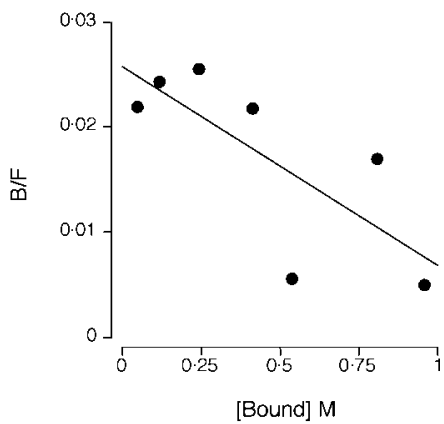

$\mathrm{D}$

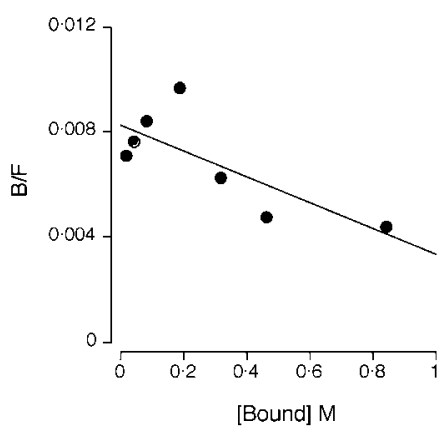

Figure 5 Saturation curves of specific binding of $\left[{ }^{3} \mathrm{H}\right]$-adenosine. Cells were incubated with increasing concentrations of $\left[{ }^{3} \mathrm{H}\right]$-adenosine. Specific binding was determined in the presence of unlabeled adenosine $(1 \mathrm{mM})$. (A) Representative saturation curve obtained in HEK 293 cells. (B) Scatchard analysis reveals a single class of limited capacity characterized by a $K_{\mathrm{d}}=1 \cdot 78 \pm 0 \cdot 35 \mu \mathrm{M}$ and $B_{\max }=2 \cdot 01 \pm 0 \cdot 15 \mathrm{fmol} / \mathrm{cell}$ in HEK 293 cells.

(C) Representative saturation curve obtained in HEK-GHS-R1a cells. (D) Scatchard analysis showed a single class of limited capacity binding site characterized by a $K_{\mathrm{d}}=6 \cdot 30 \pm$ $0.75 \mu \mathrm{M}$ and $B_{\max }=1.90 \pm 0.11 \mathrm{fmol} / \mathrm{cell}$ in HEK-GHS-R1a cells. The results are represented as means \pm s.E.M. of three independent experiments. - , total binding;

$\boldsymbol{\square}$, specific binding; $\bullet$, non-specific binding. 
(Fig. 4B), a result that might be indicative of different binding sites in the same receptor or, by contrast, different receptors for both ligands. However, saturation-binding experiments at HEK-GHS-R 1a cells with $\left[{ }^{3} \mathrm{H}\right]$-adenosine exhibited a singlebinding site with a $K_{\mathrm{d}}$ value of $6 \cdot 30 \pm 0 \cdot 75 \mu \mathrm{M}$ and a binding capacity $\left(B_{\max }\right)$ of $1 \cdot 90 \pm 0 \cdot 11 \mathrm{fmol} /$ cell. (Fig. $5 \mathrm{C}$ and D). In HEK 293 cells, $\left[{ }^{3} \mathrm{H}\right]$-adenosine saturation experiments revealed a single affinity site with a $K_{\mathrm{d}}$ value of $1.78 \pm$ $0 \cdot 35 \mu \mathrm{M}$ and a binding capacity $\left(B_{\max }\right)$ of $2 \cdot 01 \pm 0 \cdot 15 \mathrm{fmol} /$ cell (Fig. 5A and B). For the saturation experiments in HEKGHS-R1a cells, a two-site model did not give an improved fit over a one-site model (data not shown), a fact that further reinforces the suggestion that adenosine was not acting through the GHS-R1a.

A series of GHS-R1a antagonists, such as D-Lys ${ }^{3}$ GHRP-6 $(100 \mu \mathrm{M}$; Halem et al. 2004), the substance $\mathrm{P}$ analogue [D$\mathrm{Arg}^{1}{ }^{1} \mathrm{D}-\mathrm{Phe}{ }^{5}, \mathrm{D}-\mathrm{Trp}^{7,9}, \mathrm{D}-\mathrm{Leu}^{11}$ ]-substance P $(10 \mu \mathrm{M}$; Carreira et al. 2004), and BIM 28163 (10 $\mu \mathrm{M}$; Halem et al. 2004), were tested for their ability to compete for binding against $\left[{ }^{3} \mathrm{H}\right]-$ adenosine in HEK-GHS-R1a cells. None of the antagonists tested was able to compete for $\left[{ }^{3} \mathrm{H}\right]$-adenosine binding, which was solely displaced by unlabeled adenosine (Fig. 6A). In contrast, D-Lys ${ }^{3}$ GHRP-6 and substance P analogue competed for $\left[{ }^{125} \mathrm{I}\right]$-ghrelin binding in HEK-GHS-R1a cells (Fig. 6B).

\section{Assessment of internalization of GHS-R1a by confocal microscopy}

In the resting $\mathrm{CHO}$ cells that stably express the human GHS-R1a fused to EGFP (CHO-GHS-R1a cells), fluorescence was predominantly confined to plasma membrane (control, Fig. 7A). After exposure to ghrelin $(100 \mathrm{nM})$ for $20 \mathrm{~min}$, the fluorescence disappeared from the plasma membrane to be redistributed to a population of intracellular fluorescent vesicles spread throughout the cytoplasm (Fig. 7A). On the contrary, no redistribution of the fluorescent labeling was observed in cells incubated with adenosine $(100 \mu \mathrm{M})$ for $20 \mathrm{~min}$ (Fig. 7A). Large fluorescent vesicles reappeared partially at the cell surface after $60 \mathrm{~min}$ of incubation with ghrelin, while fluorescence was kept confined to the plasma membrane in cells incubated with adenosine during the same period (Fig. 7B). The lack of effect of adenosine on the GHS-R1a endocytosis supports the hypothesis that there is no direct action of adenosine on GHS-R1a. In addition, a slight reduction of the ghrelin-activated endocytosis (100 nM, $20 \mathrm{~min})$ was observed after pre-incubating the cells with adenosine $(100 \mu \mathrm{M}, 20 \mathrm{~min}$; Fig. 8), supporting a cross-talk between both receptors.

\section{Effects of $A 2 b-R$ and $A 3-R$ siRNAs}

To test the role of endogenous adenosine receptors, we analyzed the adenosine-induced intracellular calcium rise after depleting cellular levels of A2b-R or A3-R by transfecting siRNA specifically directed against each isoform in HEK-GHS-R1a cells. In the presence of a non-targeting control siRNA, the cell-surface bound $\left[{ }^{3} \mathrm{H}\right]$-adenosine was comparable to that observed without any siRNA transfection (Fig. 9A). However, both A2b-R and A3-R siRNAs effectively reduce the cell-surface bound $\left[{ }^{3} \mathrm{H}\right]$-adenosine $(46 \cdot 03 \pm 5 \cdot 71$ and $44 \cdot 47 \pm 2 \cdot 73 \%$ respectively). In the presence of a non-targeting control siRNA, adenosine $(100 \mu \mathrm{M})$ stimulated intracellular calcium mobilization on HEK-GHS-R1a cells (Fig. 9B), which was identical to that observed with any siRNA transfection (data not shown). In contrast, both A2b-R and A3-R siRNAs individually reduced the adenosine-induced calcium peak by $46 \cdot 36 \pm$ $12 \cdot 77$ and $51 \cdot 21 \pm 14 \cdot 56 \%$ respectively, suggesting that adenosine activity is in fact adenosine receptor dependent.

\section{Discussion}

In this work, our findings suggest that adenosine does not bind to the GHS-R1a, contrary to previous reports (Smith
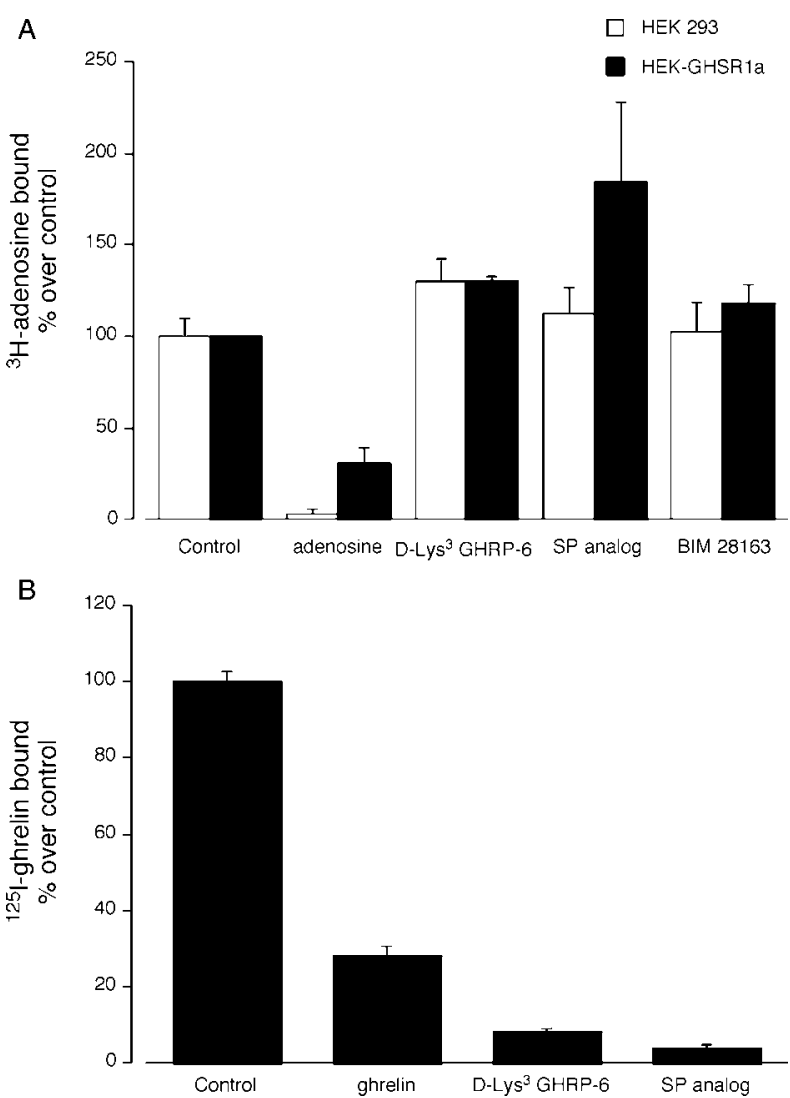

Figure 6 Effect of GHS-R1a antagonists on $\left[{ }^{3} \mathrm{H}\right]$-adenosine binding in HEK 293 (open bars) and HEK-GHS-R1a (solid bars) cells. (A) The tested compounds, D-Lys ${ }^{3}$ GHRP-6 $(100 \mu \mathrm{M})$, substance Panalogue

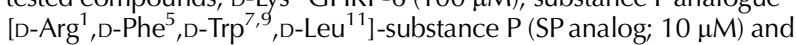
BIM $28163(10 \mu \mathrm{M})$, did not show any effect on surface bound $\left[{ }^{3} \mathrm{H}\right]$-adenosine, while unlabeled adenosine $(1 \mu \mathrm{M})$ displaced $\left[{ }^{3} \mathrm{H}\right]$ adenosine. (B) D-Lys ${ }^{3}$ GHRP-6 and substance P analogue completely displaced bound $\left[{ }^{125} \mathrm{I}\right]$-ghrelin in HEK-GHS-R1 a cells. Data $($ mean \pm S.E.M.) are from three independent triplicate experiments. 
A

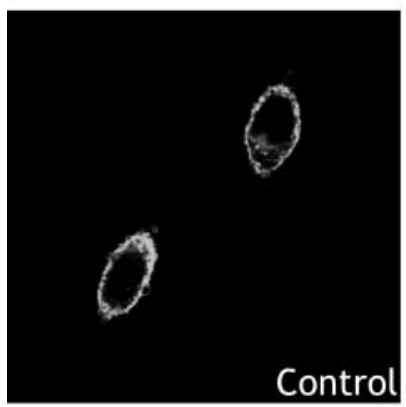

B

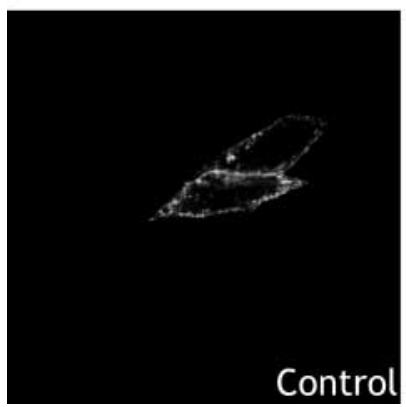

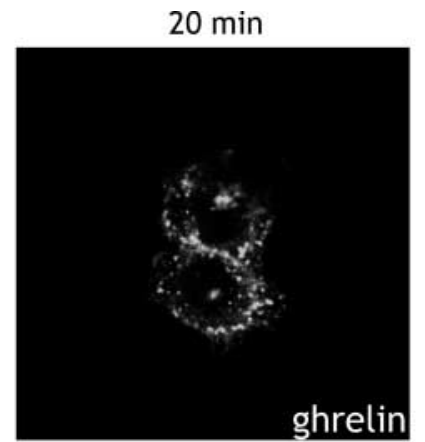

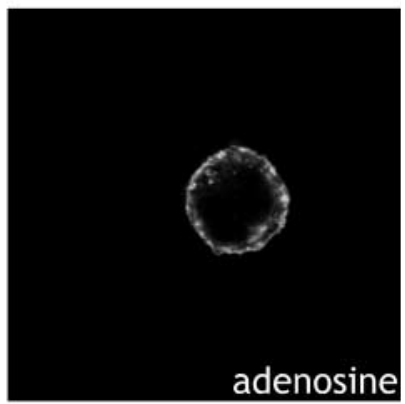

$60 \mathrm{~min}$

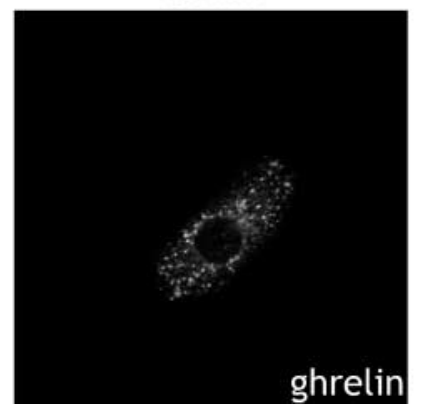

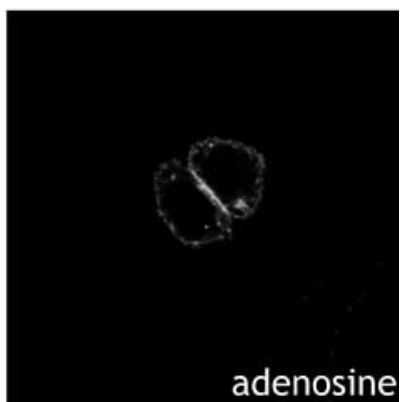

Figure 7 Internalization of the GHS-R1a in CHO cells. The localization of the GHS-R-EGFP expressed in stably transfected $\mathrm{CHO}$ cells was visualized by confocal microscopy in cells incubated for (A) 20 min and (B) 60 min at $37^{\circ} \mathrm{C}$ in the absence (control) or presence of $100 \mathrm{nM}$ ghrelin and $100 \mu \mathrm{M}$ adenosine. The images are representative of four independent experiments.

et al. 2000, Tullin et al. 2000). Despite the fact that this receptor had been considered as an example of how a single receptor may activate two distinct intracellular signaling pathways depending on the agonist (Carreira et al. 2004), the data presented so far provide sufficient evidence to discard this concept. Initially, the intracellular calcium rise induced by adenosine in HEK-GHS-R1a cells appeared to be consistent with an action mediated by the GHS-R1a as no significant calcium rise was detected in HEK 293 cells and this effect was susceptible to inhibition by the GHS-R1a antagonist $\left[\mathrm{D}-\mathrm{Arg}^{1}, \mathrm{D}-\mathrm{Ph} \mathrm{e}^{5}, \mathrm{D}-\operatorname{Trp}^{7,9}, \mathrm{D}-\mathrm{Leu}^{11}\right]$-substance P (Carreira et al. 2004); an action also detected in GHS-R1a-transfected BHK cells, the other cell line used to postulate adenosine as a ligand of the GHS-R1a (Tullin et al. 2000). Additionally, the low density of the endogenous adenosine receptor type-2b (A2b-R) in HEK-GHS-R1a cells and the lack of InPs generation supported this hypothesis (Linden et al. 1999, Smith et al. 2000, Carreira et al. 2004). In this way, adenosine seemed to activate a signaling cascade that involved the consecutive activation of AC and PKA through CTXsensitive G-protein coupled to the GHS-R1a, a finding that described the GHS-R1a as a multifaceted receptor (Carreira et al. 2004). However, a closer analysis revealed some differences between the receptor that mediates the adenosine action and the ghrelin one. First, both systems appear to be under different regulation by PKC. Phorbol ester PMA did not cause a suppression of the ghrelin-induced calcium response. On the contrary, adenosine failed to induce a calcium rise after PMA treatment, despite the clear ghrelininduced calcium response. Furthermore, PMA pretreatment inhibited the adenosine-dependent homologous desensitization, and consequently adenosine failed to attenuate the calcium response associated with ghrelin. Despite the fact that this regulatory mechanism can operate at many levels within the cell, receptor or downstream signaling, the fact that ghrelin response was recovered after a complete suppression of adenosine response is consistent with signaling pathways regulated by distinct receptors. Second, and quite remarkably, binding experiments revealed a similar binding capacity for adenosine in HEK 293 and HEK-GHS-R1a cell lines. This saturable binding indicates a single-binding site in both cell lines, a result that fits well with an equivalent expression of adenosine receptor types-2b and -3 detected by western blot analysis in both cell lines. Despite the fact that A2b-R is also endogenously expressed in BHK cells (Mittal et al. 1999), adenosine showed a binding capacity apparently higher in GHS-R1a-transfected BHK cells than in untransfected cells (Tullin et al. 2000). However, these binding studies should be carried out with higher adenosine concentrations as weak calcium responses were observed when this concentration was increased in untransfected BHK cells (Tullin et al. 2000). Even in HEK cells, there are some notable differences in the pattern 


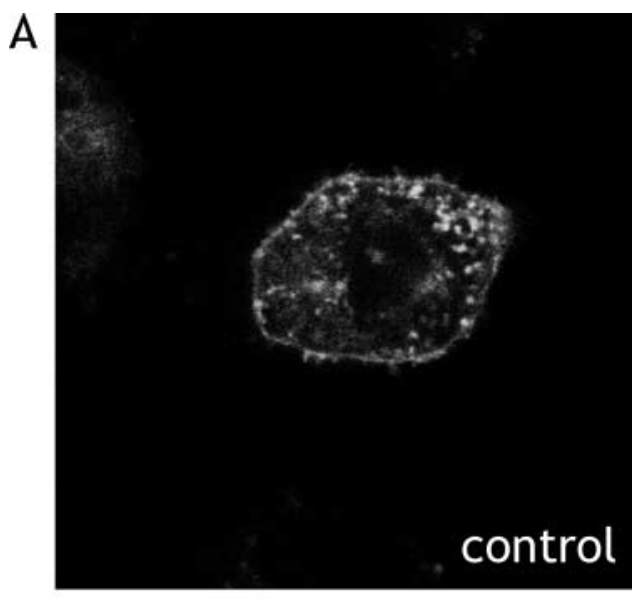

B

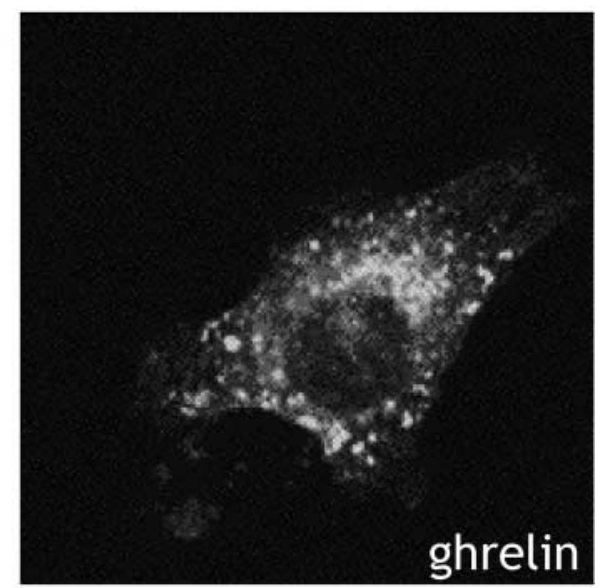

C

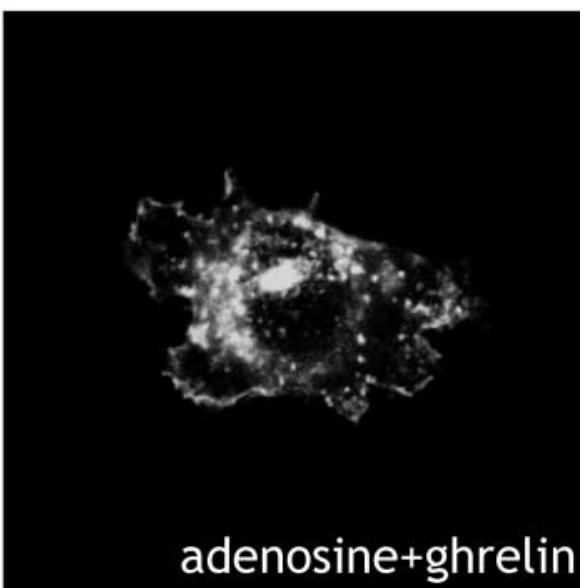

Figure 8 Effect of adenosine on ghrelin-induced GHS-R1a endocytosis in $\mathrm{CHO}$ cells. The localization of the GHS-R1a-EGFP expressed in $\mathrm{CHO}$ cells was visualized by confocal microscopy in cells stimulated with ghrelin $(100 \mathrm{nM})$, in the absence $(\mathrm{B})$ or presence of adenosine ( $1 \mathrm{mM}, 20$ min pretreatment; $\mathrm{C})$ for $20 \mathrm{~min}$ at $37^{\circ} \mathrm{C}$. The images are representative of four independent experiments. of adenosine binding at different tested concentrations. Such differences tend to disappear at high concentrations. Taken together, our findings demonstrate that adenosine is not a ligand of the GHS-R1a, and its action is mediated by the $\mathrm{A} 2 \mathrm{~b}-\mathrm{R}$ and $\mathrm{A} 3-\mathrm{R}$ in the HEK cell line. In fact, this conclusion is clearly endorsed by the reduction in adenosine functionality after depleting cellular levels of these receptors by transfecting siRNA specially directed against each isoform. This conclusion fits well with a recently published study in which evidence against adenosine analogues being partial agonists of GHS-R1a are shown (Johansson et al. 2005).

Interestingly, the activated adenosine receptor that is 'silent' in HEK 293 cells, was able to couple an intracellular signaling machinery by the presence of the GHS-R1a. This suggests an interaction between both the receptors that change the adenosine receptor properties, and consequently, its functionality. This fact could be explained by two alternative routes: either compartmentalization of signaling proteins within membrane microdomains as a consequence of overexpression of the GHS-R1a, implying that the efficiency of signal transduction is dictated by the transducer elements within microdomains (Maudsley et al. 2005), or modification of the receptor properties, including agonist affinity, potency, and efficacy, could be modified as a result of heterodimerization (Devi 2001, Rios et al. 2001, Terrillon \& Bouvier 2004). The reduction in adenosine affinity in transfected cells suggests that the latter possibility is more plausible, as a higher $K_{\mathrm{d}}$ was detected. In addition, cross-talk between heterodimeric receptor pairs can modify positively or negatively the response to agonists resulting in either enhanced-G-protein activation or cross-inhibition (Ferre et al. 1998, Jordan \& Devi 1999), even changes in G-protein-coupling specificity (George et al. 2000). In this particular case, the presence of GHS-R 1a in HEK 293 cells appears to be essential for the qualitative coupling of $A 2 b-R$ and $A 3-R$ to $G_{s}$-signaling pathway, as cAMP levels were elevated in response to adenosine in HEK-GHS-R1a cells, whereas no increase was determined in HEK 293 cells (Carreira et al. 2004). Furthermore, adenosine produces a signal attenuation of ghrelin. Decrease in the efficacy of inositol formation by ghrelin has been described in response to a combination of ghrelin and adenosine (Carreira et al. 2004). Similarly, adenosine treatment caused a partial blockade of the ghrelin-promoted internalization of the GHS-R1a, although it failed to induce GHS-R1a endocytosis, an action that seems to vary the GHS-R1a desensitization and trafficking, thus modulating the extent of receptor signaling. It thus appears that, in our experimental system, the overexpression of GHS-R1a modifies the efficacy of G-protein-coupling activities for A2b-R/A3-R with the consequent modulation of the GHS$\mathrm{R} 1 \mathrm{a}$ response. Interestingly, despite the fact that the adenosine-induced calcium rise was susceptible to inhibition by the GHS-R1a antagonist [D-Arg ${ }^{1}, \mathrm{D}-\mathrm{Phe}^{5}, \mathrm{D}-\operatorname{Trp}^{7,9}, \mathrm{D}-$ Leu ${ }^{11}$ ]-substance P (Carreira et al. 2004), the adenosine binding was unaltered by this antagonist. Although this 

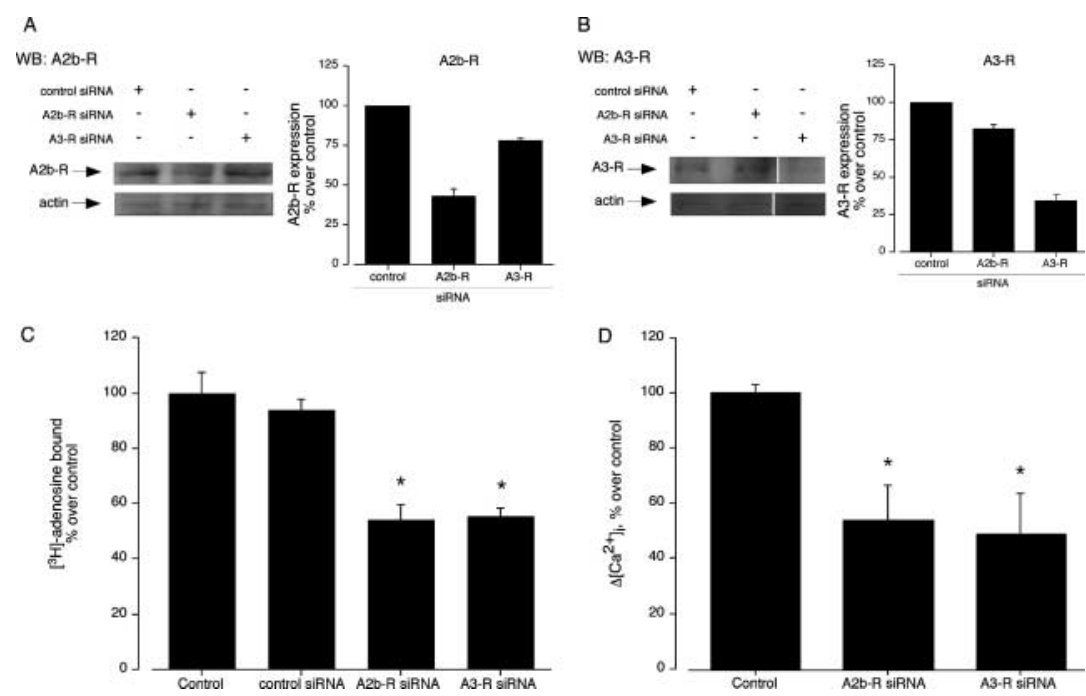

Figure 9 Effects of siRNA-suppressed A2b-R and A3-R expressions on the adenosineinduced intracellular calcium mobilization. HEK-GHS-R1a cells were transfected with the indicated siRNAs and 3 days after transfection, the efficacy of the treatments were determined by western blot ( $(A)$ for $A 2 b-R$ and $(B)$ for $A 3-R)$ and binding of $\left[{ }^{3} \mathrm{H}\right]$-adenosine at the cell surface $(C)$, and then the effect of adenosine $(100 \mu \mathrm{M})$ on intracellular calcium mobilization was evaluated (D). Each data point represents the mean \pm s.E.M. from three independent experiments (western blot).

discrepancy cannot be definitively explained at present, it is possible that this antagonist modifies the interactions between GHS-R1a and A2b-R/A3-R. Indeed, this agonist has been proven to prevent the GHS-R1a from constitutive endocytosis, with no apparent activation of GHS-R1aassociated signaling cascade (Holst et al. 2003, 2004). Even if the formation of heterodimers could have a crucial function in signal transduction, cross-talk regulation connecting the individual signaling pathways cannot be excluded.

At present, cells with high expression of a given receptor by transfection have been the preferred models for the study of receptor-associated signaling mechanisms. However, these models can lead to erroneous conclusions when used to determine the existence of 'alternative' ligands, a consequence of artifacts introduced by the high density of receptors. In this particular case, the data obtained in the present study strongly suggest that the expression of the GHSR1a in HEK 293 cells modifies a number of A2b-R and A3-R properties, including adenosine affinity, G-proteincoupling efficacy, and adenosine-activated signaling potency. Thus, the fact that a practically non-operative receptor such as the adenosine receptor can become a receptor able to 'use' or to 'modulate' the ghrelin receptor, suggests that the interaction between both receptors is a mechanism that helps to aggregate the signal transduction machinery facilitating the modulation of signaling. It is clear that further studies examining the biochemical properties of the possible ghrelin-adenosine receptor dimers are necessary to understand their physiological significance.

\section{Acknowledgements}

The expert technical assistance of Mary Lage and Sihara Pérez-Romero are greatly acknowledged. We wish to thank Dr Roy Smith (Baylor College of Medicine, Houston, USA) for the HEK-GHS-R1a cell line, and Dr Michael Culler (IPSEN, Milford, MA, USA) for the analog BIM-28163. The authors declare that there is no conflict of interest that would prejudice the impartiality of this scientific work. This work was supported by grants from the FIS, the Instituto de Salud Carlos III, Ministerio de Sanidad y Consumo, Red de Grupos RGTO (G03/028), Red de Centros RCMN (C03/08), and Secretaría Xeral de Investigación e Desenvolvemento (PGIDIT02BTF91801, PGIDIT05BTF20802PR), Xunta de Galicia. JP. Camiña is a recipient of a Research Contract from the Instituto de Salud Carlos III, Ministerio de Sanidad y Consumo, in the Research Area of the Complejo Hospitalario Universitario de Santiago.

\section{References}

Bondensgard K, Ankersen M, Thogersen H, Hansen BS, Wulff BS \& Bywater RP 2004 Recognition of privileged structures by G-protein coupled receptors. Journal of Medicinal Chemistry 47 888-899.

Camina JP, Carreira MC, El Messari S, Llorens-Cortes C, Smith RG \& Casanueva FF 2004 Desensitization and endocytosis mechanisms of ghrelin-activated growth hormone secretagogue receptor 1a. Endocrinology 145 930-940. 
Carreira MC, Camina JP, Smith RG \& Casanueva FF 2004 Agonist-specific coupling of growth hormone secretagogue receptor type 1a to different intracellular signaling systems. Role of adenosine. Neuroendocrinology 79 13-25.

Cooper J, Hill SJ \& Alexander SP 1997 An endogenous A2B adenosine receptor coupled to cyclic AMP generation in human embryonic kidney (HEK 293) cells. British Journal of Pharmacology 122 546-550.

Deghenghi R, Papotti M, Ghigo E \& Muccioli G 2001 Cortistatin, but not somatostatin, binds to growth hormone secretagogue (GHS) receptors of human pituitary gland. Journal of Endocrinological Investigation 24 RC1-RC3.

Devi LA 2001 Heterodimerization of G-protein-coupled receptors: pharmacology, signaling and trafficking. Trends in Pharmacological Sciences 22 532-537.

Feighner SD, Howard AD, Prendergast K, Palyha OC, Hreniuk DL, Nargund R, Underwood D, Tata JR, Dean DC, Tan CP et al. 1998 Structural requirements for the activation of the human growth hormone secretagogue receptor by peptide and nonpeptide secretagogues. Molecular Endocrinology 12 137-145.

Feoktistov I \& Biaggioni I 1997 Adenosine A2B receptors. Pharmacological Reviews 49 381-402.

Ferre S, Torvinen M, Antoniou K, Irenius E, Civelli O, Arenas E, Fredholm BB \& Fuxe K 1998 Adenosine A1 receptor-mediated modulation of dopamine D1 receptors in stably cotransfected fibroblast cells. Journal of Biological Chemistry 273 4718-4724.

Gao Z, Chen T, Weber MJ \& Linden J 1999 A2B adenosine and P2Y2 receptors stimulate mitogen-activated protein kinase in human embryonic kidney-293 cells. Cross-talk between cyclic AMP and protein kinase c pathways. Journal of Biological Chemistry 274 5972-5980.

George SR, Fan T, Xie Z, Tse R, Tam V, Varghese G \& O’Dowd BF 2000 Oligomerization of mu- and delta-opioid receptors. Generation of novel functional properties. Journal of Biological Chemistry 275 26128-26135.

Halem HA, Taylor JE, Dong JZ, Shen Y, Datta R, Abizaid A, Diano S, Horvath T, Zizzari P, Bluet-Pajot MT et al. 2004 Novel analogs of ghrelin: physiological and clinical implications. European Journal of Endocrinology 151 S71-S75.

Holst B, Cygankiewicz A, Jensen TH, Ankersen M \& Schwartz TW 2003 High constitutive signaling of the ghrelin receptor-identification of a potent inverse agonist. Molecular Endocrinology 17 2201-2210.

Holst B, Holliday ND, Bach A, Elling CE, Cox HM \& Schwartz TW 2004 Common structural basis for constitutive activity of the ghrelin receptor family. Journal of Biological Chemistry 279 53806-53817.

Johansson S, Fredholm BB, Hjort C, Morein T, Kull B \& Hu PS 2005 Evidence against adenosine analogues being agonists at the growth hormone secretagogue receptor. Biochemical Pharmacology 70 598-605.

Jordan BA \& Devi LA 1999 G-protein-coupled receptor heterodimerization modulates receptor function. Nature 399 697-700.

Korbonits M, Goldstone AP, Gueorguiev M \& Grossman AB 2004 Ghrelin, a hormone with multiple functions. Frontiers in Neuroendocrinology 25 27-68.

Lall S, Balthasar N, Carmignac D, Magoulas C, Sesay A, Houston P, Mathers K \& Robinson I 2004 Physiological studies of transgenic mice overexpressing growth hormone $(\mathrm{GH})$ secretagogue receptor 1A in GH-releasing hormone neurons. Endocrinology 145 1602-1611.

Linden J, Thai T, Figler H, Jin X \& Robeva AS 1999 Characterization of human $\mathrm{A}(2 \mathrm{~B})$ adenosine receptors: radioligand binding, western blotting, and coupling to $\mathrm{G}(\mathrm{q})$ in human embryonic kidney 293 cells and HMC-1 mast cells. Molecular Pharmacology 56 705-713.

Maudsley S, Martin B \& Luttrell LM 2005 The origins of diversity and specificity in G-protein-coupled receptor signaling. Journal of Pharmacology and Experimental Therapentics 314 485-494.

Mittal RA, Tan CH \& Khoo HE 1999 Evidence for A1 and A2B adenosine receptors in baby hamster kidney (BHK) cells. Biofactors 10 25-33.

Peters DM, Gies EK, Gelb CR \& Peterfreund RA 1998 Agonist-induced desensitization of A2b adenosine receptors. Biochemical Pharmacology $\mathbf{5 5}$ 873-882.

Ralevic V \& Burnstock G 1998 Receptors for purines and pyrimidines. Pharmacological Reviews 50 413-492.

Rios CD, Jordan BA, Gomes I \& Devi LA 2001 G-protein-coupled receptor dimerization: modulation of receptor function. Pharmacology $\&$ Therapeutics $9271-87$.

Shuto Y, Shibasaki T, Otagiri A, Kuriyama H, Ohata H, Tamura H, Kamegai J, Sugihara H, Oikawa S \& Wakabayashi I 2002 Hypothalamic growth hormone secretagogue receptor regulates growth hormone secretion, feeding, and adiposity. Journal of Clinical Investigation 109 1429-1436.

Smith RG, Griffin PR, Xu Y, Smith AG, Liu K, Calacay J, Feighner SD, Pong C, Leong D, Pomes A et al. 2000 Adenosine: a partial agonist of the growth hormone secretagogue receptor. Biochemical and Biophysical Research Communications 276 1306-1313.

Sun Y, Wang P, Zheng H \& Smith RG 2004 Ghrelin stimulation of growth hormone release and appetite is mediated through the growth hormone secretagogue receptor. PNAS $1014679-4684$.

Terrillon S \& Bouvier M 2004 Roles of G-protein-coupled receptors dimerization. EMBO Reports 5 30-34.

Tullin S, Hansen BS, Ankersen M, Moller J, Von Cappelen KA \& Thim L 2000 Adenosine is an agonist of the growth hormone secretagogue receptor. Endocrinology 141 3397-3402.

van der Lely AJ, Tschop M, Heiman ML \& Ghigo E 2004 Biological, physiological, pathophysiological, and pharmacological aspects of ghrelin. Endocrine Reviews 25 426-457.

Wettschureck N, Moers A, Wallenwein B, Parlow AF, Maser-Gluth C \& Offermanns S 2005 Loss of Gq/11 family G proteins in the nervous system causes pituitary somatotroph hypoplasia and dwarfism in mice. Molecular and Cellular Biology 25 1942-1948.

Received in final form 2 June 2006

Accepted 19 June 2006

Made available online as an Accepted Preprint

17 July 2006 